\title{
STUDI PENGELOLAAN OBAT SEBELUM DAN SESUDAH JKN DI PUSKESMAS JETIS KOTA YOGYAKARTA
}

\section{THE STUDY OF DRUGS MANAGEMENT BEFORE AND AFTER JKN AT PUBLIC HEALTH CENTER IN JETIS-YOGYAKARTA}

\author{
Alfira Oktaviani, Farida Baroroh ${ }^{l}$ \\ ${ }^{1}$ Fakultas Farmasi, Universitas Ahmad Dahlan \\ Jl Prof. Dr. Soepomo, Janturan, Yogyakarta Telp. (0274) 379418 \\ Email:ida_br@yahoo.com
}

\begin{abstract}
ABSTRAK
Pengelolaan obat yang efektif dan efisien sangat menentukan keberhasilan manajemen puskesmas secara keseluruhan. Pemerintah menyelenggarakan program Jaminan Kesehatan Nasional (JKN) dengan harapan dapat tercapainya kendali mutu dan biaya serta pengelolaan obat yang efektif dan efisien. Penelitian ini bertujuan untuk mengetahui pengelolaan obat sebelum dan sesudah JKN di Puskesmas Jetis Kota Yogyakarta yang meliputi perencanaan obat, permintaan obat, penerimaan obat, penyimpanan obat, pendistribusian obat, pencatatan dan pelaporan obat. Penelitian ini merupakan penelitian observasional deskriptif. Subyek penelitian dalam hal ini adalah pelaksanaan instruksi kerja puskesmas dalam pengelolaan obat. Pengumpulan data menggunakan triangulasi atau gabungan dari hasil pengamatan terstruktur dalam bentuk check list, wawancara dengan SDM yang terlibat dalam pengelolaan obat dan observasi terhadap dokumen pengelolaan obat.Teknik analisis data yang digunakan adalah deskriptif kuantitatif-kualitatif dengan persentase. Hasil penelitian menunjukkan bahwa pengelolaan obat di Puskesmas Jetis Kota Yogyakarta pada tahap perencanaan termasuk dalam kriteria baik (sebelum JKN 100\% dan setelah JKN 100\%), permintaan termasuk dalam kriteria cukup baik (sebelum JKN 63,64\% dan setelah JKN 63,64\%), penerimaan termasuk dalam kriteria baik (sebelum JKN 100\% dan setelah JKN 100\%), penyimpanan termasuk dalam kriteria baik (sebelum JKN 80,56\% dan setelah JKN 83,33\%), pendistribusian termasuk dalam kriteria baik (sebelum JKN $76,92 \%$ dan setelah JKN 84,62\%), pencatatan dan pelaporan obat termasuk dalam kriteria baik (sebelum JKN 100\% dan setelah JKN 100\%). Secara umum pengelolaan obat sebelum dan sesudah JKN di Puskesmas Jetis Kota Yogyakarta sesuai dengan standar yang berlaku dan memiliki kriteria baik dengan persentase pengelolaan obat sebelum JKN sebesar $83,91 \%$ dan pengelolaan obat setelah JKN sebesar $86,21 \%$.
\end{abstract}

Kata kunci: pengelolaan obat, jaminan kesehatan nasional, puskesmas

\begin{abstract}
The effective and efficient drugs management is very crucial in the whole success of public health center management. The government hold a program called National Health Insurance (JKN) in order to achive quality and cost control which is effective and efficient. The research was aimed to know the drugs management at the public health center in Jetis Yogyakarta which includes drug plan, drug demand, drug acceptance, drug storage, drug distribution and the process of drugs recording and reporting. This study used observasional descriptif desaign. Subjects for this study was the implementation of drugs management work instruktion in public health center .The technique data collection used triangulation or the combination among stuctured observation result in the form of check list, interview with the human rosources involved of drug management and observation the drug management documentation. The technique analysis used quantative-qualitative descriptive analysis with percentage. The results showed that the drugs management at the public health center Jetis
\end{abstract}


Yogyakarta at the drug plan, was included in both criteria (before JKN 100\% and after JKN 100\%), the drug demand was included in the criteria quite well (before JKN $63.64 \%$ and $63.64 \%$ after JKN ), the drug acceptance was included in both criteria (before JKN $100 \%$ and after JKN 100\%), the drug storage was included in both criteria (before JKN $80.56 \%$ and $83.33 \%$ after JKN), the drug distribution was included in both criteria (before JKN 76, 92\% and after JKN 84.62\%), the drug recording and reporting was included in both criteria (prior JKN after JKN 100\% and 100\%). The general drug management before and after JKN at the public health center Jetis Yogyakarta was applicable standards and good criteria with the percentage of drug management before JKN amounted to $83.91 \%$ and after JKN amounted to $86.21 \%$.

Keywords: drug management, national health insurance, public health center

\section{PENDAHULUAN}

Pengobatan merupakan kegiatan penting Puskesmas, sehingga obat-obatan pun jadi unsur penting (Anjarwati, 2010). Tujuan pengelolaan obat adalah terjaminnya ketersediaan obat yang bermutu baik, secara tepat jenis, tepat jumlah, dan tepat waktu serta digunakan secara rasional dan supaya dana yang tersedia dapat digunakan dengan sebaik-baiknya dan berkesinambungan guna memenuhi kepentingan masyarakat yang berobat ke unit pelayanan kesehatan dasar (Anonim, 2008).

Pengelolaan obat yang efisien sangat menentukan keberhasilan manajemen puskesmas secara keseluruhan, untuk menghindari perhitungan kebutuhan obat yang tidak akurat dan tidak rasional sehingga perlu dilakukan pengelolaan obat yang sesuai (Anjarwati, 2010). BPJS pada tanggal 1 Januari mulai menyelenggarakan Program Jaminan Kesehatan Nasioanal (JKN). Sejak beroperasinya BPJS Kesehatan, badan penyelenggara jaminan kesehatan seperti PT. Askes tidak lagi menyelenggarakan pelayanan kesehatan bagi pesertanya dan kementerian kesehatan tidak lagi menyelenggarakan program jaminan kesehatan masyarakat.

\footnotetext{
Puskesmas Jetis Kota Yogyakarta merupakan salah satu puskesmas yang menyelenggarakan program pelayanan kesehatan JKN. Berdasarkan latar belakang diatas, maka peneliti akan melakukan penelitian tentang studi pengelolaan obat sebelum dan sesudah JKN di Puskesmas Jetis Kota Yogyakarta.
}

\section{METODE PENELITIAN}

\section{Jenis dan Rancangan Penelitian}

Penelitian ini merupakan penelitian observasional deskriptif. Subyek penelitian dalam hal ini adalah pelaksanaan instruksi kerja puskesmas dalam pengelolaan obat. Pengumpulan data menggunakan triangulasi atau gabungan dari hasil pengamatan terstruktur dalam bentuk check list, wawancara dengan SDM yang terlibat dalam pengelolaan obat dan observasi terhadap dokumen pengelolaan obat. Teknik analisis data yang digunakan adalah deskriptif kuantitatif-kualitatif dengan persentase.

\section{Instrumen Penelitian}

Instrumen dalam penelitian ini adalah peneliti sendiri yang melakukan observasi menggunakan data primer berupa check list dan data sekunder berupa dokumen data perencanaan obat tahun 2013 dan 2014, LPLPO tahun 2013 dan 2014, kartu stok tahun 2013 dan 2014, catatan harian pemakaian obat tahun 2013 dan 2014, buku permintaan dan penerimaan obat dan alkes tahun 2013 dan 2014, SOP tahun 2013 dan 2014, arsip monitoring dan evaluasi 2013 dan 2014, DOEN 2011, FORNAS 2013 dan lain-lain.

\section{Teknik Pengumpulan Data}

Teknik pengumpulan data dalam penelitian ini adalah triangulasi atau gabungan dari hasil observasi, wawancara dan dokumentasi. Observasi dilakukan dengan pengamatan seluruh kegiatan pengelolaan obat di 
Puskesmas Jetis. Wawancara SDM yang terlibat dalam pengelolaan obat sebagai subyek penelitian.

\section{Analisis Data}

Metode yang digunakan dalam analisis data adalah metode analisis kuantitatif-kualitatif dengan pendekatan deskriptif. Pada tahap ini data akan dianalisis dan dideskripsikan dalam bentuk kata-kata untuk memperjelas hasil yang diperoleh. Data tersebut meliputi perencanaan, permintaan, penerimaan, pendistribusian, penyimpanan, serta pencatatan dan pelaporan obat (Utomo,R.D dan Latifah, E, 2013)

Berdasarkan perhitungan hasil observasi berupa check list maka range persentase dan kriteria kualitatif dapat ditetapkan sebagaimana dalam Tabel I (Arikunto, 2002).

\section{HASIL DAN PEMBAHASAN}

\section{Perencanaan obat}

Perencanaan obat adalah suatu proses kegiatan seleksi obat dan perbekalan kesehatan untuk menentukan jumlah obat dalam rangka pemenuhan kebutuhan puskesmas (Anonim, 2013f). Berdasarkan hasil observasi terhadap pelaksanaan instruksi kerja, perencanaan obat sebelum dan sesudah JKN di Puskesmas Jetis menunjukkan bahwa hasil persentase perencanaan obat $100 \%$ yang berarti memiliki kriteria "baik". Dalam perencanaan obat beberapa persyaratan telah dilaksanakan dengan baik dengan merekap data pemakaian obat dalam 1 tahun, menghitung sisa stok untuk masingmasing jenis obat dan perbekkes, merekap data usulan obat dan perbekkes dari form perencanaan obat, mengadadakan rapat perencanaan obat dan perbekkes tahunan, dan ketepatan perencanaan memenuhi kebutuhan obat.

Hasil penelitian menunjukaan bahwa perencanaan obat di Puskesmas Jetis tahun 2013 dan 2014 sudah sesuai dengan pedoman instruksi kerja perencanaan obat di Puskesmas Jetis. Perencanaan obat di Puskesmas Jetis dilakukan oleh tim perencanaan dan monitoring obat puskemas. Hasil rapat perencanaan obat ditetapkan sebagai perencanaan obat dan perbekkes puskesmas.

Tingkat ketepatan perencanaan obat sebelum JKN tahun 2013 berdasarkan perencanaan yaitu $113 \%$ dan ketepatan perencanaan berdasarkan pemakaian yaitu 90\%.Tingkat ketepatan perencanaan obat sesudah JKN tahun 2014 berdasarkan perencanaan yaitu $127 \%$ dan ketepatan perencanaan berdasarkan pemakaian yaitu $96 \%$. Perencanaan obat pada tahun 2014 mengalami peningkatan dibanding pada tahun 2013 dikarenakan prediksi kebutuhan pemakaian obat yang akan meningkat di era JKN dan pemakaian obat lebih tepat memenuhi kebutuhan sesuai dengan penerimaan obat yang diberikan oleh UPT Farmasi dan Alat Kesehatan Dinas Kesehatan Kota Yogyakarta.

\section{Permintaan obat}

Permintaan obat adalah kegiatan yang dilakukan oleh pengelola obat puskesmas dalam rangka memenuhi kebutuhan obat dan perbekalan kesehatan di masing-masing unit pelayanan kesehatan sesuai dengan pola penyakit yang ada di wilayah kerjanya (Anonim, 2013).

Tabel I. Range persentase dan kriteria kualitatif

\begin{tabular}{ccc}
\hline No & Skala & Kriteria \\
\hline 1 & $76 \% \leq$ skor $\leq 100 \%$ & Baik \\
2 & $51 \% \leq$ skor $\leq 75 \%$ & Cukup Baik \\
3 & $26 \% \leq$ skor $\leq 50 \%$ & Kurang Baik \\
4 & $0 \% \leq$ skor $\leq 25 \%$ & Tidak Baik \\
\hline
\end{tabular}


Berdasarkan hasil observasi terhadap pelaksanaan instruksi kerja, permintaan obat di Puskesmas Jetis menunjukkan bahwa hasil persentase permintaan obat sebelum JKN adalah $63,64 \%$ dan permintaan obat setelah JKN adalah $63,64 \%$ yang berarti memiliki kriteria "cukup baik". Dalam permintaan obat di Puskesmas Jetis ada beberapa persyaratan yang telah dilaksanakan diantaranya adalah menghitung pemakaian obat periode sebelumnya, menghitung jumlah kunjungan resep, menggunakan data pola penyakit, menghitung jumlah obat yang dibutuhkan dengan form LPLPO, ada metode perhitungan kebutuhan obat, menghitung rancangan permintaan periode yang akan datang, dan permintaan obat dilakukan secara rutin sesuai jadwal. Tetapi ada beberapa peryaratan yang belum dilaksanakan yaitu semua obat yang direncanakan adalah obat generik, tidak melakukan permintaan khusus, persentase pemilihan obat sesuai DOEN/ FORNAS 100\%, dan persentase peresepan obat generik $100 \%$.

Hasil penelitian menunjukkan bahwa permintaan obat tahun 2013 dan 2014 di Puskesmas Jetis sudah sesuai dengan pedoman instruksi kerja Puskesmas Jetis. petugas farmasi akan menghitung jumlah obat yang dibutuhkan dengan form Laporan Pemakaian dan Lembar Permintaan Obat (LPLPO).

Beberapa hal yang tidak sesuai dengan persyaratan yaitu tidak semua obat yang direncanakan dan diminta adalah obat generik yakni $69,91 \%$. Puskesmas Jetis memiliki kebijakan dalam pengelolaan obat sendiri yakni mengacu pada Formularium Pengobatan Dasar di Puskesmas Kota Yogyakarta. Pada Formularium Pengobatan Dasar di Puskesmas Kota Yogyakarta terdapat obat yang terdaftar di DOEN/FORNAS dan terdapat obat yang tidak terdaftar dalam DOEN/FORNAS. Formularium Pengobatan Dasar di Puskesmas Kota Yogyakarta disesuaikan dengan kebutuhan obat dan pola penyakit di Kota Yogyakarta.

\section{Penerimaan obat}

Penerimaan obat adalah kegiatan dalam menerima obat-obatan yang diserahkan oleh unit pengelola yang lebih tinggi kepada unit pengelola dibawahnya (Anonim, 2013b).
Berdasarkan hasil observasi terhadap pelaksanaan instruksi kerja, penerimaan obat sebelum dan sesudah JKN di Puskesmas Jetis menunjukkan bahwa hasil persentase penerimaan obat $100 \%$ yang berarti memiliki kriteria "baik". Dalam penerimaan obat beberapa persyaratan telah dilaksanakan dengan baik dengan ada petugas penerima obat, pengecekan kemasan obat sesuai LPLPO, pengecekan jumlah obat sesuai LPLPO, pengecekan jenis obat sesuai LPLPO, pengecekan sediaan obat sesuai LPLPO, mengecek tanggal kadaluwarsa obat, menandatangani tanda terima LPLPO, menulis bulan dan tahun kadaluwarsa obat pada box /botol obat, pencatatan dan pembukuan pada buku penerimaan obat, dan menuliskan bulan dan tahun kadaluwarsa obat dalam buku catatan kadaluwarsa obat.

Hasil penelitian menunjukaan bahwa penerimaan obat di Puskesmas Jetis tahun 2013 dan 2014 sudah sesuai dengan pedoman instruksi kerja penerimaan obat di Puskesmas Jetis. Penerimaan obat di Puskesmas Jetis dilakukan oleh petugas penerima obat, dilakukan pengecekan sesuai dengan LPLPO dan tercatat dalam buku penerimaan obat.

\section{Penyimpanan obat}

Penyimpanan obat adalah suatu kegiatan pengamanan terhadap obat yang diterima agar aman (tidak hilang), terhindar dari kerusakan fisik maupun kimia dan mutunya terjamin. (Anonim, 2013e). Berdasarkan hasil observasi terhadap pelaksanaan instruksi kerja, penyimpanan obat sebelum dan sesudah JKN di Puskesmas Jetis menunjukkan bahwa hasil persentase penyimpanan obat sebelum JKN adalah $80,56 \%$ dan penyimpanan obat setelah JKN adalah $83,33 \%$ yang berarti memiliki kriteria "baik". Dalam penyimpanan obat beberapa persyaratan telah dilaksanakan dengan baik yaitu luas minimal $3 \times 4 \mathrm{~m}^{2}$ dan atau disesuaikan dengan jumlah obat yang tersedia, ruangan kering dan tidak lembab, memiliki ventilasi yang cukup, memiliki cahaya yang cukup, lantai dibuat dari semen/ tegel/ keramik/ papan, dinding dibuat licin dan dicat warna cerah, tidak ada pembuatan sudut lantai dan dinding yang tajam, tersedia almari/laci khusus untuk narkotika dan psikotropika, ada pengukur suhu dan higrometer ruangan, obat di susun 
secara alfabetis untuk setiap bentuk sediaan, obat dirotasi dengan sistem FEFO dan FIFO, obat disimpan pada rak, obat yang disimpan pada lantai harus di letakan di atas palet, tumpukan dus sebaiknya harus sesuai dengan petunjuk, sediaan obat cairan dipisahkan dari sediaan padatan, sera, vaksin dan supositoria disimpan dalam lemari pendingin, lisol dan desinfektan diletakkan terpisah dari obat lainnya, bahanbahan mudah terbakar disimpan dalam ruangan khusus, wadah selalu tertutup rapat, ada kipas angin atau AC, silica gel tetap dalam wadah tablet dan kapsul, jendela diberi gorden, atap gedung tidak terbuat dari bahan metal, tidak ada kontak dengan benda-benda yang tajam, ruangan dikunci apabila tidak dipakai, melakukan pengamatan mutu obat secara berkala setiap bulan, tindak lanjut terhadap obat yang rusak dan kadaluwarsa, pencatatan kartu stok obat, membersihkan ruangan setiap hari.

Meskipun penyimpanan obat di Puskesmas Jetis termasuk dalam kriteria baik tetapi ada persyaratan yang belum dilaksanakan yaitu belum ada gudang digunakan khusus untuk penyimpanan obat, belum mempunyai pintu yang dilengkapi kunci ganda, kaca jendela tidak dicat putih, belum ada alat pemadam kebakaran dan mudah dijangkau, alat pemadam kebakaran belum dicek secara berkala, terdapat obat rusak dan kadaluwarsa, terdapat obat-obat yang tidak diresepkan. Pada tahun 2014 ketika pelaksanaan JKN sudah tidak terdapat obat-obat yang tidak diresepkan.

Hasil penelitian menunjukkan bahwa penyimpanan obat tahun 2013 dan 2014 di Puskesmas Jetis sebagian besar sudah sesuai dengan instruksi kerja penyimpanan obat di puskesmas. Tetapi ada beberapa persyaratan yang belum terpenuhi seperti ketersediaan alat pemadam kebakaran yang mudah terjangkau dan dicek secara berkala, padahal hal ini sangat penting mengingat ada beberapa sediaan yang disimpan di puskesmas yang sifatnya mudah terbakar. Selain itu pada tahun 2014 ketika pelaksanaan JKN, sudah mengalami perbaikan dimana tidak terdapat obat-obat yang tidak diresepkan.

\section{Distribusi obat}

Pendistribusian obat adalah kegiatan mengeluarkan dan menyerahkan obat secara bercatatan dan teratur untuk memenuhi kebutuhan sub-sub unit pelayanan kesehatan Koordinator Unit Farmasi (Anonim, 2013a). Berdasarkan hasil observasi terhadap pelaksanaan instruksi kerja, pendistribusian obat di Puskesmas Jetis menunjukkan bahwa hasil persentase pendistribusian obat sebelum JKN adalah $76,92 \%$ dan pendistribusian obat setelah JKN adalah $84,62 \%$ yang berarti memiliki kriteria "baik". Dalam distribusi obat beberapa persyaratan telah dilaksanakan dengan baik dengan tersedianya buku catatan penerimaan dan pengeluaran obat, petugas gudang obat menerima permintaan obat dari sub unit, petugas mencermati dan menyediakan sesuai permintaan sub unit, bila tidak tersedia di gudang obat petugas melakukan pengadaan permintaan bon obat ke GFK, petugas mencatat permintaan dan penerimaan untuk sub unit, petugas menyerahkan obat sesuai permintaan disertai nama dan tandatangan penerima obat, petugas memeriksa kembali obat yang akan diberikan kepada pasien, petugas memanggil pasien yang akan menerima obat, petugas menanyakan nama dan alamat pasien yang akan menerima obat adalah benarbenar pasien sesuai yang tertulis dalam resep, petugas menyerahkan obat beserta informasi penggunaan obat dan penyuluhan tentang penyakit yang diderita. Meskipun distribusi obat di Puskesmas Jetis termasuk dalam kriteria baik tetapi ada persyaratan yang belum dilaksanakan yaitu ketepatan distribusi belum memenuhi kebutuhan obat, ada kekosongan obat, persentase ketepatan pemberian obat kepada pasien belum 100\%. Pada tahun 2014 ketika pelaksanaan JKN persentase ketepatan pemberian obat kepada pasien $100 \%$.

Hasil penelitian yang dilakukan menunjukkan bahwa pendistribusian obat tahun 2013 dan 2014 di Puskesmas Jetis sebagian besar sudah sesuai dengan pedoman instruksi kerja Puskesmas Jetis. Distribusi obat yang ada di Puskesmas Jetis dilakukan dengan sistem floor stock dan individual prescribing. Selain itu pada tahun 2014 ketika pelaksanaan JKN, persentase ketepatan pemberian obat kepada pasien $100 \%$.

\section{Pencatatan dan pelaporan obat}

Pencatatan, pelaporan, dan pengarsipan merupakan rangkaian kegiatan dalam rangka penatalaksanaan obat dan bahan medis habis 
pakai secara tertib, baik obat dan bahan medis habis pakai yang diterima, disimpan, didistribusikan dan digunakan di Puskesmas atau unit pelayanan lainnya (Depkes RI, 2014b).

Berdasarkan hasil observasi terhadap pelaksanaan instruksi kerja, pencatatan dan pelaporan obat sebelum dan sesudah JKN di Puskesmas Jetis menunjukkan bahwa hasil persentase pencatatan dan pelaporan obat sebelum dan setelah JKN adalah 100\% yang berarti memiliki kriteria "baik". Dalam pencatatan dan pelaporan obat beberapa persyaratan telah dilaksanakan dengan baik dengan tersedia kartu stok, tersedia LPLPO, tiap lembar kartu stok hanya untuk mencatat data mutasi satu jenis obat, tiap baris hanya untuk mencatat satu kejadian mutasi obat, ada catatan harian pemakaian obat, ada berita acara pengambilan obat bila obat rusak atau kadaluwarsa, setiap terjadi mutasi obat langsung dicatat dalam kartu stok, pencatatan pemakaian obat harian, penerimaan dan pengeluaran dijumlah tiap akhir bulan, hasil akhir pencatatan diketahui oleh kepala puskesmas, pelaporan penggunaan obat dilakukan setiap bulan, pengiriman LPLPO sebelum tanggal 10 pada bulan berikutnya.

\section{Pengelolaan obat}

Secara umum gambaran pengelolaan obat di Puskesmas Jetis Yogyakarta sebelum JKN adalah 83,91 \%, sedangkan gambaran pengelolaan obat di Puskesmas Jetis Yogyakarta setelah JKN adalah $86,21 \%$. Pengelolaan obat yang meliputi perencanaan, permintaan, penerimaan, penyimpanan, pendistribusian dan pencatatan dan pelaporan obat sebelum JKN memiliki persetase sebesar $83,91 \%$ yang berarti "baik" dan pengelolaan obat sesudah JKN memiliki persentase sebesar $86,21 \%$ yang berarti "baik". Pengeloaan obat di Puskesmas Jetis Kota Yogyakarta sebelum maupun sesudah JKN memiliki krieteria "baik".

Pengelolaan obat secara umum di Puskesmas Jetis Kota Yogyakarta termasuk dalam kriteria baik dengan persetase sebesar 83,91\% pada tahun 2013 jika dibandingkan dengan pengelolaan obat di Puskesmas Pembantu Wates Pinggirrejo Magelang pada tahun 2013 yang termasuk dalam kriteria cukup baik dengan persetase sebesar $72,59 \%$. Berarti pengelolaan obat secara umum di Puskesmas Jetis Kota Yogyakarta lebih baik, dengan beberapa persyaratan pengelolaan obat telah dilaksanakan sesuai dengan instruksi kerja di Puskesmas Jetis Yogyakarta.

Hasil penelitian menunjukkan bahwa pengelolaan obat sesudah JKN memiliki hasil persentase yang lebih tinggi dibandingkan dengan hasil persentase pengelolaan obat sebelum JKN. Dengan demikian pelayanan kesehatan JKN dapat meningkatkan kualitas dan kinerja pengeloaan obat di Puskesmas Jetis Kota Yogyakarta.

\section{KESIMPULAN}

Pengelolaan obat di Puskesmas Jetis Kota Yogyakarta pada tahap perencanaan, penerimaan, penyimpanan, pendistribusian, pencatatan dan pelaporan obat sudah sesuai dengan standar yang berlaku dan termasuk dalam kriteria baik dengan persentase sebelum dan sesudah JKN yaitu lebih dari $76 \%$. Sedangkan pada tahap permintaan sudah sesuai dengan standar yang berlaku tetapi termasuk dalam kriteria cukup baik dengan persentase sebelum dan sesudah JKN yaitu 63,64\%. Secara umum gambaran pengelolaan obat di Puskesmas Jetis Kota Yogyakarta sebelum maupun sesudah JKN memiliki krieteria baik, sebelum JKN dengan persetase sebesar $83,91 \%$ dan sesudah JKN dengan persentase sebesar $86,21 \%$.

\section{DAFTAR PUSTAKA}

Anjarwati Rori, 2010, Evaluasi Kesesuaian Pengelolaan Obat Pada Puskesmas Dengan Standar Pengelolaan Obat Yang Ada Di Kabupaten SukoharjoTahun 2009, Fakultas Farmasi Universitas Muhammadiyah Surakarta, Surakarta

Anonim, 2008, Pedoman Teknis Pengadaan Obat Publik dan Perbekalan Kesehatan untuk Pelayanan Kesehatan Dasar, Lampiran Keputusan Menteri Kesehatan No. 1121/Menkes/SK/XII/2008 , Jakarta; diakses pada tanggal 9 September 2014 
Anonim, 2013a, 2 Juli, Pendistribusian Obat IK/FAR/007/013, No. Revisi 02, Puskesmas Jetis Kota Yogyakarta.

Anonim, 2013b, 2 Juli, Penerimaan Obat IK/FAR/013/013, No. Revisi 01, Puskesmas Jetis Kota Yogyakarta.

Anonim, 2013c, 2 Juli, Pengelolaan Obat IK/FAR/004/013, No. Revisi 02, Puskesmas Jetis Kota Yogyakarta.

Anonim, 2013d, 2 Juli, Penyerahan Obat IK/FAR/005/013, No. Revisi 02, Puskesmas Jetis Kota Yogyakarta.

Anonim, 2013e, 2 Juli, Penyimpanan Obat IK/FAR/006/013, No. Revisi 02, Puskesmas Jetis Kota Yogyakarta.

Anonim, 2013f, 2 Juli, Perencanaan Obat IK/FAR/012/013, No. Revisi 01, Puskesmas Jetis Kota Yogyakarta.

Anonim, 2013g, 2 Juli, Permintaan Obat IK/FAR/011/013, No. Revisi 01, Puskesmas Jetis Kota Yogyakarta.

Anonim, 2014, Peraturan Menteri Kesehatan RI No. 30 Tahun 2014 tentang Standar Pelayanan Kefarmasian di Puskesmas; diakses pada tanggal 30 Desember 2014
Arikunto, 2002, Prosedur Penelitian: Suatu Pendekatan Praktek, Rikena Cipta, Jakarta

Hendrawan Donni, (2013, 21 Desember), Tinjauan tentang JKN dan BPJS Serta Hubungannya dengan Profesi Farmasi, Materi dipresentasikan pada Seminar Peran Sektor Farmasi Dalam Jaminan Kesehatan Nasional dan Peluncuran Web www.kebijakanobatindonesia.net, UGM, Yogyakarta; diakses pada tanggal 12 Maret 2014

Jasaputra Diana K dan Slamet Santosa, 2008, Metodologi Penelitian Biomedis, PT. Danamartha Sejahtera Utama, Bandung; p. $47-50$

Sugiyono, 2012, Metode Penelitian Kuantitatif, Kualitatif dan $R \& D$, Alfabeta, Bandung; $\mathrm{p}$. 215-221, 225, 269-277

Utomo, R.D dan Latifah, E, 2013, Profil Pengelolaan Obat di Puskesmas Pembantu Wates Pinggirrejo Magelang Juli 2013, Jurnal penelitian dipublikasikan di Prosiding Seminar Nasional Universitas Muhammadiyah Magelang ISSN : 23553588 ; diakses pada tanggal 18 September 2014. 
